\title{
Oocyte In Vitro Maturation with Crude Sperm Extract Protein of Bull's Spermatozoa
}

\author{
Bilqis $^{1}$, Sri Rahayu ${ }^{2}$, Gatot Ciptadi ${ }^{3}$ \\ ${ }^{1}$ Master Program of Biology, Faculty of Mathematics and Natural Sciences, University of Brawijaya, Malang, Indonesia \\ ${ }^{2}$ Department of Biology, Faculty of Mathematics and Natural Sciences, University of Brawijaya, Malang, Indonesia \\ ${ }^{3}$ Department of Animal Production, Faculty of Animal Husbandry, University of Brawijaya, Malang, Indonesia
}

\begin{abstract}
Oocyte In vitro maturation (IVM) is one of the important parts for in vitro fertilization (IVF). The success of oocyte maturation is influenced by the composit ion and the quality of IVM medium. Culture medium which used to IVM not only influences the oocyte process to reach metaphase II and proceed the fertilization, but also influences to developmental of an embryo. Crude sperm extract has high-level protein kinase and contains some sperm proteins. Crude sperm extracts expected as natural maturation medium that can increase the success of In Vitro Maturation (IVM). The characterization of crude sperm extracts profile with sodium dodecyl sulfate-polyacrylamide gel electrophoresis (SDS-PAGE). Oocyte maturation is observed in the $26^{\text {th }}$ hour from the first culture. The result of crude sperm extract characterization obtained from the protein with the molecular weight is $176.8,63.2,58.4,55.3,52.4$, $49.7,44.6,38.02,36.03,34.15$ and $26.8 \mathrm{kDa}$. Oocyte maturation with concentration of crude sperm extract $1.5 \mu \mathrm{g} . \mathrm{mL}^{-1}$ with $71.6 \%$ matures oocyte and oocyte maturation with concentration of crude sperm extract $2.5 \mu \mathrm{g} . \mathrm{mL}^{-1}$ with $75 \%$ matures oocyte.
\end{abstract}

Keywords: Crude Sperm Extract, In Vitro Maturation, Oocyte

\section{INTRODUCTION}

In vitro maturation (IVM) in the oocyte is one of the important phases on in vitro fertilization [1]. One of the obtained benefits from In vitro maturation (IVM) is the availability of adult oocyte as the source of recipient cytoplasm to nucleus transfer program, so that it is possible to increase embryo in vitro production [2].

Efficiency embryo production in vitro is highly affected by the number and the quality of the oocyte which is successful to be mature oocyte [3]. The success of oocyte maturation is affected by the composition and the quality of the used medium [4]. The main compositions which are commonly used to increase the quality of culture medium are protein and hormone [1]. The sperm extract which has high-level protein kinase and it contain some protein in the sperm [5]. The protein kinase can trigger the increase of Maturation promoting factor (MPF) which is the enzyme kinase which has a significant role to continue transition oocyte phase from mitosis to meiosis [6]. Activated MPF (Maturation Promoting Factor) is needed as the beginning of maturation [7].

\footnotetext{
* Correspondence author:

Bilqis

Email : bilqis.bil7@gmail.com

Address : Master Program of Biology, University of Brawijaya, Jl. Veteran Malang, 65145
}

In the present research, the crude sperm extract given by oocyte maturation medium aims to determine developmental of Goat oocyte. Thus it can inform the success of IVM which contains some Bull sperm protein as oocyte maturation medium from the different species.

\section{MATERIALS AND METHODS Isolation and Characterization of Bull's Sperm Protein}

The crude spermatozoa extract is isolated and prepared from the masculine bull ejaculator. The semen is obtained from BBIB (Balai Besar Inseminasi Buatan - Artificial Insemination Institution) in Singosari. The fresh bull's semen is taken $2 \mathrm{ml}$ added with PBS (Phosphat Buffer Saline) until 6 $\mathrm{ml}$, centrifuge at $2500 \mathrm{rpm} 10$ minutes. The pellet is added with TCM $199 \mathrm{Ph} 7.4$ as $3 \mathrm{~mL}$, then centrifuge at $2500 \mathrm{rpm} 10$ minutes. The pellet is added with buffer extract as $0.5 \mathrm{~mL}$ and mix until homogeny. The obtained suspense is done by cold sonication with amplitude $50 \%$ along 20 minutes. Total of $1 \mathrm{~mL}$ suspense in centrifuge $9000 \mathrm{rpm}$ along 30 minutes temperature $4^{\circ} \mathrm{C}$, the obtained supernatant is taken from $1 \mathrm{~mL}$ and centrifuged $13000 \mathrm{rpm}$ along 45 minutes temperature $4^{\circ} \mathrm{C}$. The obtained supernatant is added with buffer KCL-HEPES as $0.5 \mathrm{~mL}$ or with $1: 1$ comparison, and then it keeps at $-80^{\circ} \mathrm{C}$. The iso- 
lated sperm protein extract was characterized with $12.5 \%$ separating gel SDS-PAGE protocol.

\section{Oocyte Treatment}

Goat Oocyte used is oocyte grade A that have three layers of cumulus. They were divided into 3 groups: control group $\left(\mathrm{P}_{0}\right)$; IVM medium without crude sperm extract (medium TCM $199+10 \%$ Fetal Bovine Serum SA Origin (FBS, GIBCO) and added with the gonadotrophin hormone supplementation as $15 \mu \mathrm{LFSH}$ and $35 \mu \mathrm{L} \mathrm{LH} \mathrm{[9]).} \mathrm{P}_{1}$ : IVM medium with supplementation crude sperm extract concentration $1.5 \mu \mathrm{g} \cdot \mathrm{mL}^{-1}$. $\mathrm{P}_{2}$ : IVM medium with supplementation crude sperm extract concentration $2.5 \mu \mathrm{g} \cdot \mathrm{mL}^{-1}$. All groups was insert in incubator at $5 \% \mathrm{CO}_{2}, 38.5^{\circ} \mathrm{C}$ of humidity, in drop medium $100 \mu \mathrm{L}$ per 10 oocytes which is layered by paraffin oil.

\section{Data Analysis}

The data of sperm protein character is analyzed descriptively to measure the molecular weight of protein in the bull sperm. The data of oocyte maturation were used to analyze the number of mature oocytes descriptively and then analyzed using One Way Anova.

\section{RESULT AND DISCUSSION}

The result of SDS-PAGE characterization shows that the protein in the crude sperm extract has some molecular weight which is 176.8 , 63.2, 58.4, 55.3, 52.4, 49.7, 44.6, 38.02, 36.03, 34.15 and $26.8 \mathrm{kDa}$. Maturation oocyte is the physiologist process which aims to provide oocyte to fertilization. The maturation process of the oocyte in vitro in this research using TCM 199 medium which is added with the $\mathrm{LH}, \mathrm{FSH}$, and FBS serum, maturation medium has an important role to the success of oocyte maturation in vitro. Thus the effort of maturation medium with some supplementations maximizes the success of oocyte maturation in vitro. There are three treatments used in this research, which is $P_{0}$ as maturation control medium, P1 as the treatment of maturation medium with crude sperm extract concentration $1.5 \mu \mathrm{g} \cdot \mathrm{mL}^{-1}$, and $P_{2}$ as the treatment of maturation medium with crude sperm extract concentration $2.5 \mu \mathrm{g} \cdot \mathrm{mL}^{-1}$. Maturation oocyte in various treatments showed in Figure 1.

The maturation without treatment (maturation control) shows that from the obtained 75 oocytes, there are 45 mature oocytes observed from oocyte cumulus expansion. Thus, it can be assumed that the success of oocyte maturation is about $60 \%$. Oocyte maturation treatment with crude sperm extract concentration $1.5 \mu \mathrm{g} \cdot \mathrm{mL}^{-1}$ from 67 oocytes, 48 oocytes matured. Thus the success of oocyte maturation is about $71.6 \%$. While treatment of maturation medium with crude sperm extracts concentration $2.5 \mu \mathrm{g} \cdot \mathrm{mL}^{-1}$ from 48 oocytes, there are 36 oocytes matured and the success of oocyte maturation is about $75 \%$ (Table 1). The result of this research shows that the crude sperm extract protein can trigger oocyte maturation. Higher concentration gives higher chance for more oocyte to be mature.
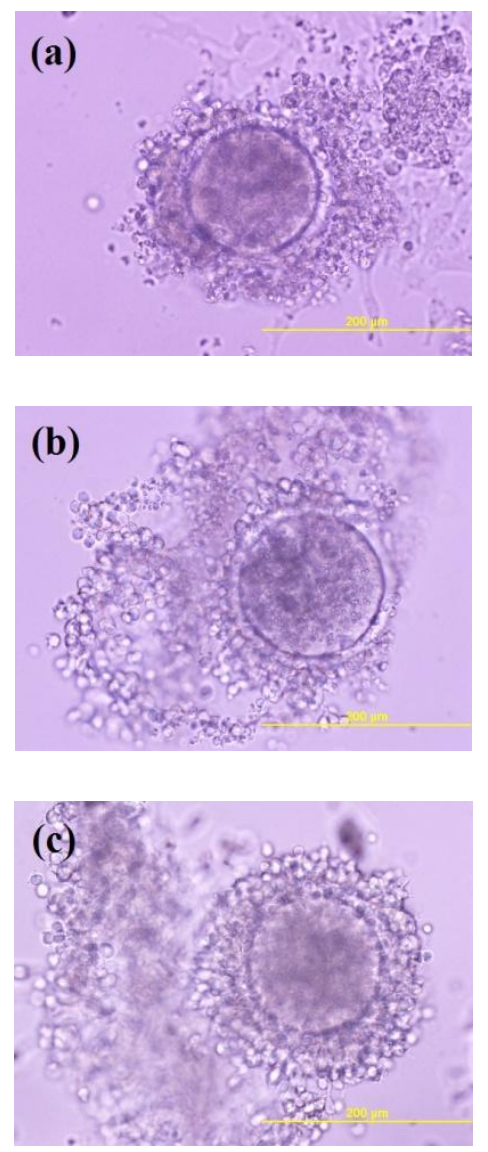

Figure 1. The result of IVM Description:

(a) Oocyte with the maturation control treatment

(b) Oocyte with treatment CSE concentration $1.5 \mu \mathrm{g} \cdot \mathrm{mL}^{-1}$ (c) Oocyte with treatment CSE concentration $2.5 \mu \mathrm{g} \cdot \mathrm{mL}^{-1}$ The observation used the inverted microscope 200x.

Table 1. The result of the goat's oocyte maturation

\begin{tabular}{lccc}
\hline \multicolumn{1}{c}{ Treatment } & $\begin{array}{c}\text { Total } \\
\text { Oocyte }\end{array}$ & $\begin{array}{c}\text { Total Mature } \\
\text { Oocyte }\end{array}$ & \% \\
\hline $\mathrm{P}_{0}$ : Control & 75 & 45 & 60 \\
\hline $\mathrm{P}_{1}: \mathrm{SE} 1.5 \mu \mathrm{g} \cdot \mathrm{mL}^{-1}$ & 67 & 48 & 71 \\
\hline $\mathrm{P}_{2}$ : SE $2.5 \mu \mathrm{g} \cdot \mathrm{mL}^{-1}$ & 48 & 36 & 75 \\
\hline
\end{tabular}

Note: cultured 26 hours in the incubator $5 \% \mathrm{CO}_{2} 37^{\circ} \mathrm{C}$ 
The result of analysis of every treatment shows that there is a difference, treatment crude sperm extract concentration $1.5 \mu \mathrm{g} \cdot \mathrm{mL}^{-1} \mathrm{I}$ and 2.5 $\mu \mathrm{g} \cdot \mathrm{mL}^{-1}$ gives more increases percentage of maturation compared to control treatment. Between treatments of crude sperm extract concentration, the treatment $2.5 \mu \mathrm{g} \cdot \mathrm{mL}^{-1}$ has bigger percentage of success in maturating the oocyte. However, from those treatments, the number of oocyte which is successfully maturated shows few differences, so that the statistical analysis does not show any significant differences from each treatment.

Figure 1 show a morphological change from the three oocyte maturation treatments. The higher concentration of crude sperm extracts treatment, the higher number of mature oocyte. The characteristics of the mature oocyte can be seen from the cumulus expansion, the radiate corona seems shiny, zone pellucid seems clear, ooplasm is hygiene, the granulose cell has good expansion. Good quality of MII oocyte is the clean oocyte, the cytoplasm granular, and the clear zone pellucid [10]. The cumulus cells expansion start to be seen on the incubation of 26-48 hours which is indicated by the presence of $\mathrm{cu}$ mulus ooforus [11].

The protein kinase can decrease synthesis of Cyclin AMP (CAMP). The decrease of cAMP synthesis is needed to increase the production of maturation promoting factor (MPF). The increase of MPF production has significant role to continue the phase from meiosis I to meiosis II in oocyte so that the beginning of maturation [12]. The present research proves that the giving of crude sperm extract can increase the number of a mature oocyte.

\section{CONCLUSION}

Crude sperm extract supplementation in a medium can trigger the goat oocyte maturation. The success of maturation with crude sperm extract supplementation concentration $1.5 \mu \mathrm{g} \cdot \mathrm{mL}^{-1}$ is $71.6 \%$. Besides, the success of oocyte maturation with supplementation crude sperm extract concentration $2.5 \mu \mathrm{g} \cdot \mathrm{mL}^{-1}$ is $75 \%$. Crude sperm extract concentration $2.5 \mu \mathrm{g} \cdot \mathrm{mL}^{-1}$ optimizing better for in vitro maturation of oocytes.

\section{ACKNOWLEDGEMENT}

Authors would like thank to research LPDP RISPRO, realization of the cell bank of gametes (Spermatozoa) local goat and bull for the cryopreservation and commercialization germplasm Indonesia, Contract No PRI-1047LPDP/2015.

\section{REFERENCES}

[1] Zheng, Y.S., M.A. Sirard. 1992. The effect of sera, bovine serum albumin and follicular cells on in vitro maturation and fertilization of porcine oocytes. Theriogenology. 37. 779-790.

[2] Ciptadi, G., S.B. Sumitro. 2011. Imunokontrasepsi (eksperimen interaksi spermatozoa dan oosit). Airlangga University Press: Surabaya.

[3] Kharche. S.D., H.S. Birade. 2013. Parthenogenesis and activation of mammalian oocytes for in vitro embryo production: A review. Adv. Biosci. Biotech. 4. 170-182.

[4] Wattimena, J. 2011. Pematangan oosit domba secara in vitro dalam berbagai jenis serum. Agrinimal. 1(1). 22-27.

[5] Wahyuni, E.A. 2009. Isolasi dan karakterisasi protein Crude Sperm Extract kambing dan sapi: uji potensi CSE $100 \mathrm{kDa}$ dalam mengaktivasi sel oosit. Master Thesis. Faculty of Mathematics and Natural Sciences, University of Brawijaya: Malang.

[6] Doree, M., T. Hunt. 2002. From Cdc2 to Cdk1: when did the cell cycle kinase join its cyclin partner? J. Cell Sci. 115. 2461-2464.

[7] Schmitt, A., A.R. Nebreda. 2002. Signalling pathways in oocyte meiotic maturation. J. Cell Sci. 115. 2457-2459.

[8] Wang, Z.G., Z.R. Zu, S.D. Yu. 2007. Effects of oocyte collection techniques and maturation media on in vitro maturation and subsequent embryo development in boer goat. Czech. J. Anim. Sci. 52(1).21-25.

[9] Tanaka, H. 2001. Reproductive biology and biotechnology. JICA, Japan International Cooperation Agency: Indonesia.

[10] Balaban B., B. Urman. 2006. Effect of oocyte morphology on embryo development and implantation. Reprod. BioMed. 12(1). 59-66.

[11] Madison, B., T. Greve, V. Avery, H. Callsen, P. Hyteel. 1993. Production of bovine embryos, a progess report and conseguences on the genetic upgrading of catlle population. J. Anim. Reprod. Sci. 33. 51-69.

[12] Voronina, E., G.M. Wessel. 2003. The regulation of oocyte maturation. Current Topics in Developmental Biology Vol. 58. Elsevier. 